\title{
DA METÁFORA AO LITERAL - JACQUES LACAN com Arnaldo Antunes
}

\author{
Maritza de Magalhães Garcia
}

Este trabalho privilegia um trajeto no ensino de Jacques Lacan que vai de sua peculiar apropriação do conceito linguístico de significante, incluindo suas bases teóricas em Sigmund Freud, até sua teorização de lalíngua, que delimita o inconsciente formulado como um saber que ultrapassa o que se pode chamar de linguagem. Trata-se de um saber-fazer com restos de palavras que constitui a própria matéria de que o inconsciente é feito. Esse percurso segue elementos determinados da teoria lacaniana: a estruturação do inconsciente como uma linguagem, os mecanismos de constituição da metáfora e a concepção de letra, indo da palavra metafórica, que circula como bem ou mal-entendido, ao seu osso, à letra que constitui a matéria corporal que resta da palavra. A psicose é abordada tanto como o lugar onde a metáfora é construída por uma via diferente da que produz a significação corrente, quanto na vertente das singulares invençôes no trabalho com a letra. A poesia de Arnaldo Antunes mapeia o percurso apresentando um modo de construção com a materialidade da palavra que nos ensina sobre a psicose, bem como sobre o trabalho do psicanalista com a fala.

BANCA:

Marcus André Vieira (Orientadora)

Ana Lucia Lutterbach Holck

Ana Maria Rudge

Angélica Bastos de Freitas Rachid Grimberg

Sérgio Augusto Chagas de Laia

Data da defesa: 29/03/2010 